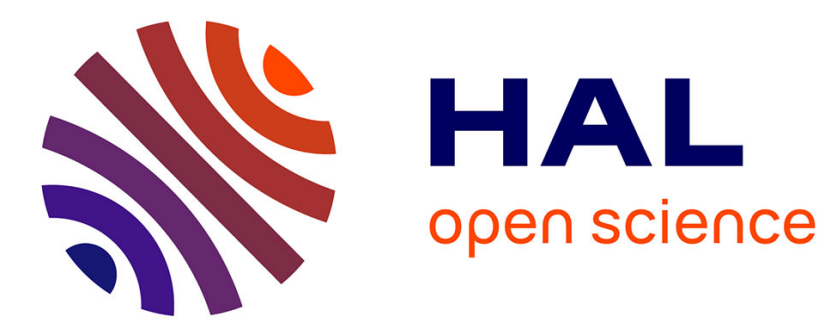

\title{
The antitumor effects of an arsthinol-cyclodextrin complex in a heterotopic mouse model of glioma
}

Selma Becherirat, Marie-Claire Lanhers, Marie Socha, Mehdi Yemloul, Alain Astier, Caroline Loboda, Nathalia Aniceto, Stéphane Gibaud

\section{- To cite this version:}

Selma Becherirat, Marie-Claire Lanhers, Marie Socha, Mehdi Yemloul, Alain Astier, et al.. The antitumor effects of an arsthinol-cyclodextrin complex in a heterotopic mouse model of glioma. European Journal of Pharmaceutics and Biopharmaceutics, 2013, 83 (3 Pt A), pp.560-568. 10.1016/j.ejpb.2013.06.021 . hal-01169157

\section{HAL Id: hal-01169157 https://hal.science/hal-01169157}

Submitted on 5 Jul 2015

HAL is a multi-disciplinary open access archive for the deposit and dissemination of scientific research documents, whether they are published or not. The documents may come from teaching and research institutions in France or abroad, or from public or private research centers.
L'archive ouverte pluridisciplinaire HAL, est destinée au dépôt et à la diffusion de documents scientifiques de niveau recherche, publiés ou non, émanant des établissements d'enseignement et de recherche français ou étrangers, des laboratoires publics ou privés. 


\section{The antitumor effects of an arsthinol-cyclodextrin complex in an heterotopic mouse model of glioma}

Selma Becherirat ${ }^{\mathrm{a}}$, Marie-Claire Lanhers ${ }^{\mathrm{b}}$, Marie Socha ${ }^{\mathrm{a}}$, Mehdi Yemloul ${ }^{\mathrm{c}}$, Alain Astier $^{\mathrm{d}}$, Caroline Loboda ${ }^{\mathrm{a}}$, Nathalia Aniceto ${ }^{\mathrm{a}}$ and Stéphane Gibaud ${ }^{\mathrm{a}^{*}}$

a : EA 3452 - CITHEFOR - Université de Lorraine - 5, rue Albert Lebrun (Faculté de pharmacie) 54000 Nancy - France

b : EA 4421 - SIGRETO - Université de Lorraine - 9, avenue de la forêt de Haye (Faculté de médecine) - 54500 Vandœuvre-lès-Nancy - France

c : Méthodologie RMN (CRM2, UMR 7036 CNRS-Nancy-Université), Faculté des Sciences et Technologies, BP 70239, 54506 Vandœuvre-lès-Nancy Cedex, France

d : Pharmacy -Toxicology Department, CHU Henri Mondor, 51 avenue du Maréchal de Lattre, 94010, Créteil, France

*Corresponding author. Tel.: +33 3836823 10; fax: +33 3836823 01. E-mail address:

stephane.gibaud@univ-lorraine.fr 


\section{Abstract}

In this paper, we examined arsthinol-cyclodextrin complexes, which display an anticancer activity. The association constants were $17502 \pm 522 \mathrm{M}^{-1}$ for hydroxypropyl- $\beta$-cyclodextrin and $12038 \pm 10168 \mathrm{M}^{-1}$ for randomized methylated $\beta$ cyclodextrin. ${ }^{1} \mathrm{H}-\mathrm{NMR}$ experiments in solution also confirmed the formation of these complexes and demonstrated an insertion of the arsthinol (STB) with its dithiarsolane extremity into the wide rim of the hydroxypropyl- $\beta$-cyclodextrin cavity. Complexed arsthinol was more effective than arsenic trioxide $\left(\mathrm{As}_{2} \mathrm{O}_{3}\right)$ and melarsoprol on the U87 MG cell line. Importantly, in the in vivo study, we observed significant antitumor activity against heterotopic xenografts, after i.p. administration and did not see any signs of toxicity. This remains to be verified using an orthotopic model.

Keywords: glioma; glioblastoma; arsenic; cancer; brain tumors 


\section{Introduction}

Although brain tumors are relatively rare, they represent approximately $2 \%$ of all cancer diseases and constitute an important cause of morbidity and mortality. The age-adjusted SEER ${ }^{1}$ (Surveillance Epidemiology and End Results from the National Cancer Institute) incidence of brain tumors is approximately $6.6 / 100000$ in the United States [1]. Gliomas comprise approximately $33 \%$ of all brain tumors and $79 \%$ of malignant brain tumors [2]. It is a group of heterogeneous neoplasms that differ in location within the central nervous system, age and sex distribution, growth potential, invasiveness, morphological features, tendency for progression and response to treatments. The most common malignant glioma is the glioblastoma, which is associated with a median survival of $12-15$ months.

Temozolomide is an oral drug that is rapidly metabolized into methyltriazenoimidazole-carboxamide $\left(\mathrm{MTIC}^{2}\right)$, a DNA-methylating drug. A DNA repair enzyme, methyl-guanine methyltransferase $\left(\mathrm{MGMT}^{3}\right)$, can remove the methyl group and overcome the modification of cells that lack MGMT, which have been shown to have a higher sensitivity to temozolomide. The EORTC ${ }^{4}$ (European Organization for Research and Treatment of Cancer) has published a study on the concomitant use of radiation therapy and adjuvant temozolomide, which slightly improved mortality (9.8\% after 5 years). This treatment is now adopted as the new standard treatment.

In addition to temozolomide, other compounds (bevacizumab, VEGF receptor tyrosine kinase inhibitors [pazopanib, lapatinib, erlotinib], procarbazine, lomustine and vincristine) have been tested in clinical trials, but only the phase II studies have

\footnotetext{
${ }^{1}$ SEER : Surveillance Epidemiology and End Results from the National Cancer Institute

2 MTIC : methyltriazeno-imidazole-carboxamide

${ }^{3}$ MGMT : methyl-guanine methyltransferase

${ }^{4}$ EORTC : European Organization for Research and Treatment of Cancer
} 
been published. Low molecular weight kinase inhibitors may have advantages in terms of drug delivery, whereas monoclonal antibodies have greater specificity but face delivery restrictions. To date, few molecularly targeted therapies have demonstrated significant antineoplastic activity, possibly due to tumor heterogeneity. Arsenic trioxide $\left(\mathrm{As}_{2} \mathrm{O}_{3}\right)$ has also been shown to be effective in glioma cells and in mice models. This compound can induce autophagy and apoptosis [3], and it inhibits at relatively low concentrations in U87 and T98G cells in vitro [4]. This finding was confirmed with orthotopic malignant gliomas growing in the brains of mice but only in combination with radiotherapy [5].

In this paper, we focus on an organoarsenical drug (i.e., Arsthinol, STB ${ }^{5}$, Fig.1), which displays an anticancer activity. This drug was marketed in 1953 as amoebicide tablets [6, 7], and it has recently demonstrated a strong anticancer activity after intravenous (i.v.) injections [8-13].

From a chemical perspective, STB belongs to the dithiarsolane series, which includes melarsoprol (MEL $\left.B^{6}\right)$ as the lead compound. This latter drug is used as a trypanocide in Africa, and its formulation in propylene glycol can lead to adverse side effects, often causing severe pain for patients during i.v. injection. Because these drugs are very poorly soluble in water, we also suspect their precipitation in plasma as soon as the drug enters the vein and is diluted in the blood, which can lead to thrombosis in some cases.

The i.v. use of the drug has also been limited because of its cerebral toxicity. After injection, the rapid increase in concentration can lead to arsenical encephalopathy.

\footnotetext{
5 STB : arsthinol

6 MEL B : melarsopol
} 
A few years ago, we proposed cyclodextrin $\left(C D^{7}\right)$ complexes (hydroxypropyl- $\beta-$ cyclodextrin/melarsoprol and methyl-B-cyclodextrin/melarsoprol) that could allow for oral absorption [14]. These complexes were characterized by an improved absorption and reduced peak/valley ratio. As expected, the tolerance for this formulation was better, and surprisingly, the therapeutic effect was also significantly improved, with no CNS toxicity observed at therapeutic dose [15].

We attempted to apply this concept to STB/cyclodextrin complexes. This dithiarsolane was chosen because it has the best anticancer activity of this series of compounds, to our knowledge $[11,13,16]$.

\section{Materials and methods}

\subsection{Materials}

STB and melarsoprol were synthesized according to the method described by Friedheim $[9,17,18]$. Its chemical structure is presented in Fig. 1. The organoarsenic purity was greater than $99 \%$, confirmed by the HPLC analysis, and its structure was ascertained by ${ }^{1} \mathrm{H}$ - and ${ }^{13} \mathrm{C}$-NMR.

The cyclodextrins [randomly methylated- $\beta-$ cyclodextrin (1.6-2.0 methyl unit per anhydroglucose unit; RAMEßCD) and hydroxypropyl-B-cyclodextrin (HPBCD)] were purchased from Sigma-Aldrich (St. Quentin, France). In all experiments, the water content of the CDs was determined by the coulometric Karl-Fisher method and then the weighed mass of the CDs was adjusted accordingly. All other reagents were of analytical grade from either VWR (Fontenay-sous-Bois, France) or Sigma-Aldrich (St. Quentin, France) and were used as received. RPMI 1640 with Glutamax-I and

${ }^{7} \mathrm{CD}:$ cyclodextrin 
antibiotic/antimycotic were purchased from Gibco (Gibco Invitrogen, Cergy Pontoise, France).

\subsection{Characterization of $S T B^{\star} C D$ complexes}

\subsubsection{HPLC assay for STB quantification}

STB samples were analyzed using a reverse-phase high performance liquid chromatography (HPLC). Twenty microliters of each sample were injected, using a Spectra Physics $®$ AS1000 injector, onto a C18 column (Nucleosil@ 100-5 C18 AB, $5 \mu \mathrm{m}, 240 \times 4 \mathrm{~mm}$, Macherey-Nagel, Eckbolsheim, France). The samples were eluted at a flow rate of $1.0 \mathrm{~mL} / \mathrm{min}$ (Spectra Physics P1000XR, Thermo Electron S.A., France) with a mobile phase consisting of acetonitrile and acetic acid $0.6 \%(45: 55$, $\mathrm{v} / \mathrm{v})$. The elution took place at room temperature under isocratic conditions. In these analytical conditions, the limit of detection was $0.12 \mu \mathrm{M}$ and the limit of quantification was $0.39 \mu \mathrm{M}$. Standard solutions $(1.5 \mu \mathrm{M}$ to $20 \mu \mathrm{M})$ used to build the standard curve $(\mathrm{CV}<3.5 \%)$ were prepared by dissolving the appropriate amount of powdered drug in methanol and bringing the solution up to the final volume with phosphate buffer (0.1 M, pH 7.4).

\subsubsection{Phase solubility studies of STB complexation}

STB complexation with various cyclodextrins was evaluated using the phasesolubility method [19]. A suspension of a large excess of STB in $2 \mathrm{~mL}$ of aqueous solutions of the appropriate CD (concentrations ranging from 9.5 to $191 \mathrm{mM}$ in $0.1 \mathrm{M}$ phosphate buffer $\mathrm{pH}$ 7.4) was stirred in screw-capped amber vials for $18 \mathrm{~h}$ on a rockand-roller agitator at $25^{\circ} \mathrm{C}$. Under these conditions, the solution primarily contained 
the non-ionized STB (pKa 9.5, [20]), and no significant degradation of the drug was observed. Preliminary time-dependence experiments showed that the equilibrium was reached after this period of stirring. Each suspension was then centrifuged at $7200 \times \mathrm{g}$ for $5 \mathrm{~min}$ and diluted 1:100 with $0.1 \mathrm{M}$ phosphate buffer $\mathrm{pH} 7.4$; the amount of dissolved STB was then quantified by HPLC as described above.

The apparent solubility of the substrate ([STB $\left.]_{t}\right)$ was determined as a function of the added ligand concentration $\left([C D]_{t}\right)$. Because the phase solubility diagrams were of $\mathrm{A}_{\mathrm{L}}$-type and a 1:1 complex was assumed, the apparent stability (or formation) constant $K_{c}$ was calculated for each CD using the slope from the linear regression analysis of the phase-solubility isotherm using the following equation: $K_{c}=\frac{\text { slope }}{S_{0} \cdot(1-\text { slope })} \quad$ Eq. (1)

The inherent solubility of STB $\left(S_{0}\right)$ was determined in pure water under identical conditions. The determinations were performed in triplicate, and the constants were expressed as the mean \pm S.D.

2.2.3. Determination of the apparent complexation constant by potentiometric titration

For the potentiometric titration procedure, a set of solutions with increasing concentrations of $\mathrm{CD}\left(2.5 \times 10^{-5}\right.$ to $\left.6 \times 10^{-5} \mathrm{M}\right)$ and a constant drug content $\left(1 \times 10^{-5}\right.$ M) were prepared, with a final volume of $16 \mathrm{~mL}$.

To maintain the ionic strength, phosphate buffer $(0.1 \mathrm{M}, \mathrm{pH} 7.4)$ was used. A control STB solution was also prepared in the phosphate buffer medium without CD to 
calculate the reference $\mathrm{K}_{\mathrm{a}}$ value. After one hour of incubation at room temperature to allow for complexation, the solutions were acidified to $\mathrm{pH} 4$ with $0.05 \mathrm{M} \mathrm{HCl}$ and then $0.05 \mathrm{M} \mathrm{KOH}$ was added progressively up to $\mathrm{pH} 11$ to form the titration curve. After each $\mathrm{KOH}$ addition, the $\mathrm{pH}$ was recorded. The $\mathrm{pH}$ and titrant volumes were used to calculate the $\mathrm{K}_{\mathrm{a}}$ value through the second derivative method [21].

The apparent complexation constant was calculated as previously described by Kahle and colleagues [22].

\subsubsection{Determination of the complex structure by ${ }^{1} \mathrm{H}-\mathrm{NMR}$ measurements}

Because the results that we obtained were similar for both cyclodextrins, we chose to focus on HPBCD for the remainder of the study. Additionally, this cyclodextrin was already complexed with melarsoprol and this drug has now an "orphan drug designation" from the European Medicine Agency (i.e., trypanocidal activity of the melarsoprol/HPBCD complex [15]). The results from ${ }^{1} \mathrm{H}$ NMR, ${ }^{13} \mathrm{C} N M R$, ROESY, NOESY, HSQC, and 2D-HSQC-NOESY analyses of HPBCD and the complex (STB*HPBCD) were obtained at $298 \mathrm{~K}$ in $\mathrm{D}_{2} \mathrm{O}$ on a Bruker Avance III $600 \mathrm{MHZ}$ using a $5 \mathrm{~mm}$ broad band direct probe. Spectral widths of $6000 \mathrm{~Hz}$ and $30000 \mathrm{~Hz}$ were used for ${ }^{1} \mathrm{H}$ NMR and ${ }^{13} \mathrm{C}$ NMR, respectively. 2D NMR spectra were acquired by pulse field gradient-selected methods. 2D ROESY spectrum was acquired with a 2048 time domain in F2 and 256 experiments in F1, using the TPPI method and a mixing (spin-lock) time of $300 \mathrm{~ms}$ at a field of approximately $4 \mathrm{kHz}$.

The 2D HSQC-NOESY spectra were recorded with a 4096 time domain in F2 and 256 experiments in F1 using the Echo-Antiecho method and a mixing time of 500 ms. 


\subsection{Cell cultures - in vitro activity on U87MG cells}

U87 MG glioma cells were cultured in monolayers $\left(37^{\circ} \mathrm{C}, 5 \% \mathrm{CO}_{2}\right)$ in $\mathrm{DMEM}$ supplemented with fetal calf serum (10\%), an antibiotic mixture of penicillin and streptomycin (1\%) and glutamine (1\%). Coarse STB and MEL were dissolved in DMSO leading to final concentrations of DMSO $<1 \%$ (blank controls of DMSO did not show any toxicity) ; STB*HPBCD was spontaneously dissolved in the culture medium.

The classical MTT test was used to determine growth inhibition and cytotoxic activity after treatment with STB, STB*HPBCD, $\mathrm{As}_{2} \mathrm{O}_{3}$ or melarsoprol. Exponentially growing cells were seeded into 96 -well plates $\left(4 \times 10^{4}\right.$ cells $\left./ \mathrm{mL}\right)$ and incubated with each compound at different concentrations $\left(0.01 \mu \mathrm{M}\right.$ to $1 \mathrm{mM}, 24 \mathrm{~h}$ or $48 \mathrm{~h}, 37^{\circ} \mathrm{C}, 5 \%$ $\left.\mathrm{CO}_{2}\right)$. Cell viability was directly proportional to the production of formazan $(\lambda=570$ $\mathrm{nm})$.

\subsection{Animal studies}

Pathogen-free, 6-8 week-old female athymic NMRI-nu (nu/nu) mice were purchased from Charles River (Saint Germain sur l'Arbresle, France).

Animal handling procedures were performed in accordance with national animal care guidelines (European Commission directive 86/609/CEE; French decree no. 87-848). Animals were housed in solid-bottomed plastic cages with free access to tap water and food ad libitum. Rearing conditions were a room temperature of $23 \pm 1^{\circ} \mathrm{C}$, a relative humidity of $60 \%$, and a $12 \mathrm{~h} / 12 \mathrm{~h}$ light/dark cycle. 


\subsubsection{Maximum Tolerated Dose (MTD)}

Maximum Tolerated Doses (MTD) were determined to set the doses of animal experiments. Groups of 5 animals have received various doses of STB*RAMEBCD and $\mathrm{As}_{2} \mathrm{O}_{3}$ (i.p. and oral) 5 days/week. The first dose was set from our experience of these compounds [9] $\left(0.15 \mathrm{mmol} / \mathrm{kg}\right.$ for $\mathrm{STB}^{\star} \mathrm{RAMEBCD}$ and $0.06 \mathrm{mmol} / \mathrm{kg}$ for $\left.\mathrm{As}_{2} \mathrm{O}_{3}\right)$ and was increased by steps of $0.01 \mathrm{mmol} / \mathrm{kg}$. The highest dose that results in no lethality, $<15 \%$ weight loss and no other sign of toxicity was recorded as MTD.

\subsubsection{Glioma mouse model}

U87 MG is a commonly studied grade IV glioma cell line (anaplastic astrocytoma, ATCC HTB-14) that has been studied for more than four decades. These cells were cultured in monolayers as described above.

Heterotopic tumor grafts were achieved as followed: a subcutaneous injection of $10^{6}$ U87 MG cells (in 5\% glucose) was performed into each hind leg of mice. Tumors obtained from these source mice were used for the production of heterotopic transplants, by subcutaneous implantation (inguinal area) of a fragment of approximately $2 \mathrm{~mm}^{3}$ in new mice, under anesthesia. Three successive subcutaneous relocations were performed in other mice, when tumors reached approximately $1000 \mathrm{~mm}^{3}$, before using for our experiment (subcutaneous implantation of a $2 \mathrm{~mm}^{3}$ fragment in experimental mice). The size of the tumor was assessed with a vernier caliper (large diameter $=D$ and small diameter $=d$ ) to obtain the volume $(\mathrm{V}=\mathrm{D} \times \mathrm{d})^{2} / 2$. 
Treatments started when the volume of the tumor exceeded $280 \pm 50 \mathrm{~mm}^{3}$, and the solutions [STB* RAMEBCD (i.p. and oral), arsenic trioxide (i.p. and oral)] were administered 5 days/week. Each group (treated and control) was composed of 9 mice.

Since the route of administration were i.p. and oral, the bioavailability is always bellow $100 \%$ and this may impact the efficacy of the treatment, we chose to compare each group at $65 \%$ of the MTD (see section 3.5).

The size of the tumor was measured with a vernier caliper 3 times a week. Experiments were stopped when the size reached $2000 \mathrm{~mm}^{3}$ (survival endpoint).

Other ethical parameters inconsistent with the continued life of animals, such as a weight loss of greater than $15 \%$ of initial weight, major disturbances in physiological and/or neurological functions, were also taken into account as endpoints.

The Mann-Whitney $U$ test was used to evaluate the statistical significance of the results. Kaplan-Meier curve analysis was performed for survival analysis, using the log-rank test (GraphPad Prism version 5.00 for Mac Os X, GraphPad Software, San Diego California USA).

\subsubsection{Arsenic concentration in the organs after oral and i.p. administration}

Brains, tumors, kidney, spleens, intestines and livers were removed from all the animals when the survival endpoint was reached $(2 \mathrm{~h} 30 \mathrm{~min}$ after the last administration). The organs were weighed and stored at $-20^{\circ} \mathrm{C}$ until analysis.

The amount of total arsenic in the samples was determined using a colorimetric method [23] after digestion with nitric acid $\left(\mathrm{HNO}_{3} ; 65 \%\right)$ and hydrogen peroxide 
$\left(\mathrm{H}_{2} \mathrm{O}_{2} ; 30 \%\right)$. In brief, each sample (tissues or plasma) was placed in a digestion tube with $5 \mathrm{~mL} \mathrm{HNO}_{3}(65 \%)$ and $5 \mathrm{~mL} \mathrm{H}_{2} \mathrm{O}_{2}$ (30\%). The tubes were heated with a digester apparatus DK-20 (Velp Scientifica, Milan, Italy) by slowly increasing the temperature from $100^{\circ} \mathrm{C}$ to $200^{\circ} \mathrm{C}$. The clear solution was evaporated to dryness, and the residue was solubilized with $10 \mathrm{~mL}$ of $\mathrm{HCl}(2 \mathrm{M})$ and introduced into an arsine generator apparatus (European Pharmacopoeia). The reaction was initiated by zinc powder after reduction to trivalent arsenic $\left(\mathrm{As}{ }^{\mathrm{III}}\right)$ with tin chloride $\left(\mathrm{SnCl}_{2}\right.$; $40 \%$ ) and potassium iodide (KI; 15\%). After $30 \mathrm{~min}$, the pentavalent arsenic (As ${ }^{\mathrm{V}}$ ) was completely reduced to arsine $\left(\mathrm{AsH}_{3}\right)$, and the gas bubbled through a solution of the silver salt of diethyldithiocarbamate in pyridine. The absorbance of the brown complex was measured at $525 \mathrm{~nm}$ (Cary-50 spectrophotometer, Varian, Palo Alto, USA). A calibration curve was obtained with increasing amounts of arsenic $\left(\mathrm{As}_{2} \mathrm{O}_{3}\right.$, 0-0.09 mmol, $\mathrm{n}=3, \mathrm{CV}<4.2 \%)$. 


\section{Results and discussion}

\subsection{Characterization of $S T B^{\star} C D$ complexes}

\subsubsection{Phase solubility studies of STB complexation}

Our main objective was to develop a complex of STB with cyclodextrins (STB* RAMEBCD and STB*HPBCD). To our knowledge, this STB compound was the best anticancer dithiarsolane [9,13]; it is a lipophilic compound $(\log P=2.34)$, and its solubility is very poor, though slightly better than that of melarsoprol.

The classical phase solubility study, first described by T. Higuchi and K.A. Connors [19], demonstrates the potent solubility properties of cyclodextrins. RAMEBCD and HPBCD showed a very good solubilization effect on STB (Fig. 2). Both cyclodextrins isotherms were linear within the CD concentration range studied, corresponding to $A_{L}$-type profile with a slope less than 1 and indicating that the inclusion complexes could be of the first order with respect to the CDs (1:1 stoichiometry).

In this case, the method can be used for the determination of $\mathrm{K}_{\mathrm{c}}$ using the slope of the curve. However, the standard deviation was very large $\left(24058 \pm 20738 \mathrm{M}^{-1}\right.$ for HPBCD and $18697 \pm 7426 \mathrm{M}^{-1}$ for RAMEßCD). Therefore, these results should be confirmed by another method. 
3.1.2. Determination of the apparent complexation constant by potentiometric

titration

Potentiometric titration offers several advantages in terms of simplicity and accuracy over many methods [27-31].

The dissociation equilibria in $\mathrm{STB}^{\star} \mathrm{CD}$ solutions correspond to Eq. (2) and Eq.(3)

$\mathbf{K}_{\mathbf{a}}^{\mathbf{S T B}^{\mathrm{T}}}=\frac{\left[\mathrm{H}^{+}\right] \cdot\left[\mathrm{STB}^{-}\right]}{[\mathrm{STB}]}$

$\mathbf{K}_{\mathbf{a}}^{\mathrm{STB}}=\frac{\left[\mathrm{H}^{+}\right] \cdot\left[\mathrm{STB}^{-*} \mathrm{CD}\right]}{\left[\mathrm{STB}^{*} \mathrm{CD}\right]}$

$\mathbf{K}_{\mathbf{a}}^{\prime}$ corresponds to the apparent $\mathbf{K}_{\mathbf{a}}$ of $S T B / C D$ mixtures and depends on the concentration of each species.

Thus, for the 1:1 complex, the CDs may form an inclusion complex with both STB and STB- According to Connors and Lipari [32], Eq.(2) and Eq.(3) lead to the following equation in which:

$$
\frac{K_{a}^{\prime}}{K_{\mathrm{v}}^{\mathrm{STB}}}=1+\frac{\left(\mathrm{K}_{\mathrm{c}}^{\mathrm{STR}}-\mathrm{K}_{\mathrm{c}}^{\mathrm{STB}}\right) \cdot[\mathrm{CD}]}{1+\mathrm{K}_{\mathrm{c}}^{\mathrm{STB}}}
$$

This equation can be expressed in a double reciprocal (Benesi-Hildebrand or Lineweaver-Burk) form as follows:

$\frac{K_{a}^{\prime}}{K_{a}^{\prime}-K_{a}^{\text {STB }}}=\frac{1}{\left(K_{c}^{\text {STB }}-K_{c}^{\text {STB }}\right) \cdot[C D]}+\frac{K_{c}^{\text {STB }}}{\left(K_{c}^{\text {STB- }}-K_{c}^{\text {STB }}\right)}$ 
This formula can be used for plotting the experimental data ( $\mathbf{p} \mathbf{K}_{\mathbf{a}}^{\prime}$ or $\mathbf{K}_{\mathbf{a}}^{\prime}$ values) in a linearized form where $[C D]$ is the free cyclodextrin concentration $\left(\approx[C D]_{t}-[S T B]_{t}\right)$, $[C D]_{t}$ is the total cyclodextrin concentration and [STB $]_{t}$ the total STB concentration. By plotting $\mathbf{K}_{\mathbf{a}}^{\text {STB }} /\left(\mathbf{K}_{\mathbf{a}}^{\prime}-\mathbf{K}_{\mathbf{a}}^{\text {STB }}\right)$ as a function of $1 /\left([C D]_{t}-[S T B]_{t}\right), \quad \mathbf{K}_{c}^{\text {STB }}$ and $\mathbf{K}_{c}^{\text {STB- }}$ are obtained as follows (Fig. 3):

$\mathrm{K}_{\mathrm{c}}^{\mathrm{STB}}=\frac{\text { ordinate intercept }}{\text { slope }}$

$K_{c}^{S T B-}=\frac{1+\text { ordinate intercept }}{\text { slope }}$

The first titration curve (i.e., without CD) displays the $\mathrm{pK}_{\mathrm{a}}$ of STB $(9.61 \pm 0.12$ [Fig. 3]) and was consistent with the value published by Hiskey in 1968 [20].

The determination of the complexation constant gave $\mathbf{K}_{\mathrm{c}}^{\mathrm{STB}}=17502 \pm 522 \mathrm{M}^{-1}$ and $\mathrm{K}_{\mathrm{c}}^{\mathrm{STB}-}=20835 \pm 67 \mathrm{M}^{-1}$ for $\mathrm{HPBCD}$, and $\mathrm{K}_{\mathrm{c}}^{\mathrm{STB}}=12038 \pm 10168 \mathrm{M}^{-1}$ and $\mathrm{K}_{\mathrm{c}}^{\mathrm{STB}-}=$ $37038 \pm 13113 \mathrm{M}^{-1}$ for RAMEßCD.

These values were consistent with those of the dissolution study. We therefore considered this complexation to have a very strong association.

\subsubsection{Determination of the complex structure by ${ }^{1} \mathrm{H}-\mathrm{NMR}$ measurements}

A 2D-ROESY experiment was used to characterize the inclusion complex of STB and 2-hydroxypropyl- $\beta$-cyclodextrin. This technique is widely used and enables the 
identification of host-guest intermolecular interactions [33]. In our case, the overlapping of the STB peaks (b, c, d, g, Table 1) with those of cyclodextrin (between 3.5 and $4 \mathrm{ppm}$ ) and the variation of chemical shifts when passing from pure solution to complex and when changing the solvent made the identification of intermolecular cross peaks with the aromatic portion ambiguous (Fig. 4a).

To avoid this problem and clearly identify the complex, we used the large spectral dispersion of ${ }^{13} \mathrm{C}$ through the $2 \mathrm{D}-\mathrm{HSQC} / \mathrm{NOESY}$ sequence, which provides a conventional 2D HSQC spectrum correlating the chemical shifts of ${ }^{13} \mathrm{C}$ in the $\mathrm{F} 1$ dimension (vertical) and protons in the F2 dimension (horizontal), in which there are two types of cross peaks for each ${ }^{13} \mathrm{C}$ resonance: the direct coupling ${ }^{1} \mathrm{~J}(\mathrm{CH})$ and the NOE ${ }^{1} \mathrm{H}-{ }^{13} \mathrm{C}$ due to the cumulative transfer of ${ }^{1} \mathrm{~J}(\mathrm{CH})+{ }^{1} \mathrm{H}-{ }^{1} \mathrm{H}$ NOE.

The intensities of the NOESY correlation peaks allowed us to characterize, in relative terms, the interatomic distances. From these intensities (green circles, Fig. 4b), we can say that the proton $\left(e^{\prime}\right)$ is the nearest proton of 5 and 6 , followed by the proton (e) and finally the proton (f) (whose correlation can result from relayed interactions, not from direct spatial proximity).

This study suggests that the aromatic ring is deeply inserted into the cavity following the scheme proposed in Fig. 5.

\subsection{In vitro activity}

The results have confirmed that this organoarsenical drug, such as arsenic trioxide [3], has a potential for the treatment of glioma. 
Because STB was more cytotoxic than $\mathrm{A}_{2} \mathrm{O}_{3}$, the toxicity/activity ratio (therapeutic index T.I. $=\mathrm{LD}_{50} / \mathrm{IC}_{50}$ ) was used for a better comparison among the three compounds. The $\mathrm{LD}_{50}$ values were previously published [9], and the $\mathrm{IC}_{50}$ values were taken from the $48 \mathrm{~h}$ time point (Fig 6). The T.I. ratio, which was 16.8 for $\mathrm{As}_{2} \mathrm{O}_{3}$ and 12.6 for melarsoprol, was significantly improved for STB (T.I. = 143).

Until this study, dithiarsolanes (i.e., melarsoprol or STB) had not been tested for the treatment of glioma, and the only proven use of these compounds for treating cancer had been described for leukemias [24]. During the last decade, the anticancer properties of trivalent arsenical derivatives have been partially elucidated. Their strong activity has been attributed to the linkage between the arsenical compounds and the thiol moieties present on numerous proteins.

$\mathrm{As}_{2} \mathrm{O}_{3}$ is the main arsenical compound that has been studied and tested on a series of glioma cells (U373, U87, U251, GBI, A-172 and T98G) [25]. The $\mathrm{IC}_{50}$ of $\mathrm{As}_{2} \mathrm{O}_{3}(<2$ $\mu \mathrm{M})$ was considered as clinically safe. This compound induces autophagy at low concentrations but induces apoptosis at higher concentrations (approximately 8 $16 \mu \mathrm{M}$ ). BNIP3 (Bcl-2/adenovirus E1B 19-kDa-interacting protein 3) is upregulated in $\mathrm{As}_{2} \mathrm{O}_{3}$-induced autophagic cells and seems to play a central role in arsenic-induced autophagic cell death in malignant glioma cells [26].

Since STB ${ }^{*}$ PBCD is administered orally and necessarily dissociated during digestion, the $\mathrm{IC}_{50}$ of STB is relevant to discuss the efficacy of this compound. Nevertheless, we have shown that the cytotoxicity of this complex is $31,6 \pm 9.7 \mu \mathrm{M}$. 


\subsection{In vivo experiments}

The MTD are detailed in table 2. These results confirm that STB*RAMEBCD has a lower toxicity than $\mathrm{As}_{2} \mathrm{O}_{3}$ and are in good agreement with the results previously obtained for STB $L D_{50}[9]$.

In subsequent experiments, we chose doses of $65 \%$ of the MTD for administration of i.p. $S T B^{\star} R A M E B C D$, i.p. $\mathrm{As}_{2} \mathrm{O}_{3}$ and oral $\mathrm{As}_{2} \mathrm{O}_{3}$. For oral $\mathrm{STB}^{\star} \mathrm{RAMEBCD}$, the MTD was too high, and for technical reasons, it was not possible to give more than 3 $\mathrm{mmol} / \mathrm{kg}$; consequently, this dose was arbitrarily fixed at $10 \times$ the i.p. dose (Table 2).

During the treatment of the tumor-bearing mice, the animals were inspected daily for signs of pain, distress or morbidity.

The evaluation of overall clinical condition included general appearance and behaviour (dehydration, wasting away, hypothermia, laboured respiration, wound, ruffled fur, abnormal vocalization, abnormal posture, lethargy, impaired behaviour as hyper- or hypoactivity, ataxia, circling, tremors, convulsions). For the i.p. treatments, we were vigilant about ulcerations or inflammations near the injection area.

For each curve, a progressive growth (Fig. 7) of the average tumor volume has been observed in the first days until the first animal until the first animal died.

Compared with the control group, the average tumor volume increases more slowly after i.p. administration of $\mathrm{As}_{2} \mathrm{O}_{3}$ or STB*HPBCD (Fig. 7a).

The Kaplan-Maier survival curves are shown in Fig.8a, and the differences between these two groups (i.e., $\mathrm{As}_{2} \mathrm{O}_{3}$ i.p. and $\mathrm{STB}^{*} \mathrm{HPBCD}$ i.p.) are significant $(\mathrm{p}=0.049$, log-rank [Mantel Cox] test). The median survival after $\mathrm{As}_{2} \mathrm{O}_{3}$ i.p. treatment was 15 days a very near that of the control group (14 days), whereas survival after 
STB*HPBCD i.p. treatment reached 21 days (Fig. 9) and was statistically different from that of the other groups $(p<0.05)$.

The effects observed per os were not statistically different from those of the control group (Fig 7b, 8b). The median survival of the controls was 13 days. It reached 14 days with $\mathrm{As}_{2} \mathrm{O}_{3}$ per os and 17 days with STB*HPBCD per os.

Arsenic amount was analyzed in different organs of few mice treated with STB/HPBCD during 28 days (the maximum duration for per os treatment). It was detected in liver and brain for the i.p. group, and in liver, spleen, kidney, small intestine and brain for the per os group.

For this last group, low concentrations of arsenic were found in the liver and spleen (Table 3). Higher concentrations were found in the intestine (202 nmol/g), most likely due to the route of administration.

The arsenic concentrations in the heterotopic tumors were $21 \mathrm{nmol} / \mathrm{g}$ and $14 \mathrm{nmol} / \mathrm{g}$ after i.p. and oral administration, respectively. These values has to be compared with the $\mathrm{IC}_{50}(2.8 \pm 0.7 \mu \mathrm{M}$ after $48 \mathrm{~h})$ and the $\mathrm{IC}_{90}(29.9 \pm 8.7 \mu \mathrm{M}$ after $48 \mathrm{~h})$ which are very near these tissue concentrations (Fig. 6).

Not surprisingly, the brain, which contains important amounts of membrane lipids, has high concentrations of the drug $(693 \mathrm{nmol} / \mathrm{g}$ and $217 \mathrm{nmol} / \mathrm{g}$ after i.p. and oral administration, respectively). This finding confirms other i.v. studies performed with melarsoprol and STB [34].

The concentrations of arsenic in the heterotopic tumors were not very high $(21 \mathrm{nmol} / \mathrm{g}$ and $14 \mathrm{nmol} / \mathrm{g}$ after i.p. and oral administration, respectively), although the efficacy was good. This study was performed on heterotopic tumors, which were 
chosen as a first step for their simplicity. However, an orthotopic tumor would likely be impacted by the high concentrations of drug in the brain tissue. 


\section{Conclusion}

This paper demonstrates that the very poorly soluble drug STB forms a 1:1 inclusion complex with both cyclodextrins (HPBCD and RAMEBCD).

The association constants determined by the solubility method and by potentiometry are high and in good agreement for both methods. The values are also closely related for both CDs (HPBCD and RAMEBCD), suggesting a similar inclusion process.

${ }^{1} \mathrm{H}-\mathrm{NMR}$ experiments in solution also confirmed the formation of the complexes and demonstrated an insertion of the STB with its dithiarsolane extremity into the wide rim of the CD cavity.

Complexed STB (STB*HPBCD) was more effective than arsenic trioxide $\left(\mathrm{As}_{2} \mathrm{O}_{3}\right)$ and melarsoprol on the U87MG cell line. Importantly, the in vivo study did not show any signs of toxicity, and we observed a significant antitumor activity after i.p. administration.

Consequently, we consider that this treatment is promising, and we believe that the oral route is suitable for this type of drug. The oral complexed melarsoprol that we have studied in previous studies, which is quite similar, gave very good results in a CNS-trypanosomiasis mouse model (i.e., no signs of toxicity and a resolution of CNS-stage infections). 


\section{References}

[1] N. Howlader, A. Noone, M. Krapcho, N. Neyman, R. Aminou, W. Waldron, S. Altekruse, C. Kosary, J. Ruhl, Z. Tatalovich, H. Cho, A. Mariotto, M. Eisner, D. Lewis, H. Chen, E. Feuer, K. Cronin, SEER Cancer Statistics Review, 1975-2009 (Vintage 2009 Populations), National Cancer Institute. Bethesda, MD, http://seer.cancer.gov/csr/1975_2009_pops09/, based on November 2011 SEER data submission, posted to the SEER web site, April 2012, 2012.

[2] C. Corle, M. Makale, S. Kesari, Cell phones and glioma risk: a review of the evidence., J. Neuro-oncol., 106 (2012) 1-13.

[3] H.-W. Chiu, Y.-S. Ho, Y.-J. Wang, Arsenic trioxide induces autophagy and apoptosis in human glioma cells in vitro and in vivo through downregulation of survivin, J. Mol. Med., 89 (2011) 927-941.

[4] S. Zhao, T. Tsuchida, K. Kawakami, C. Shi, K. Kawamoto, Effect of As2O3 on cell cycle progression and cyclins D1 and B1 expression in two glioblastoma cell lines differing in p53 status, Int. J. Oncol., 21 (2002) 49-55.

[5] F. Jiang, X. Zhang, S. Kalkanis, Z. Zhang, H. Yang, M. Katakowski, X. Hong, X. Zheng, Z. Zhu, M. Chopp, Combination therapy with antiangiogenic treatment and photodynamic therapy for the nude mouse bearing U87 glioblastoma, Photochem. Photobiol., 84 (2008) 128-137.

[6] Anonyme, New and nonofficial remedies; arsthinol, J Am. Med. Assoc., 152 (1953) 531.

[7] S. Gibaud, G. Jaouen, Arsenic - based drugs: from Fowler's solution to modern anticancer chemotherapy, Top. Organomet. Chem., 32 (2010) 1-20.

[8] A. Astier, S. Gibaud, Use of organoarsenic or oraganoantimony derivatives for their anticancer properties, WO Patent 2005/034935 A1, 2005.

[9] S. Gibaud, R. Alfonsi, P. Mutzenhardt, I. Fries, A. Astier, (2-Phenyl-[1, 3, 2] dithiarsolan-4-yl)-methanol derivatives show in vitro antileukemic activity, $\mathrm{J}$ Organomet. Chem., 691 (2006) 1081-1084.

[10] S. Gibaud, A. Astier, Organoarsenicals derived from 2-phenyl[1,3,2]dithiarsolan- 4-yl)-methanol (AsIII) with antileukaemic properties: from trypanosomicides to anticancer drugs, Ann. Pharm. Fr., 65 (2007) 162-168.

[11] I. Ajana, A. Astier, S. Gibaud, Arsthinol for the treatment of leukaemia: a new look at an old treatment, Oncologie, 11 (2009) S34-S35.

[12] I. Ajana, A. Astier, M.C. Lanhers, B. Demoré, M. Socha, S. Gibaud, 1217 Dithiarsolanes in the treatment of glioma: in vitro activity on U87 cell line and brain concentrations on a mouse model, Eur. J. Cancer Suppl., 7 (2009) 125. 
[13] I. Ajana, A. Astier, S. Gibaud, Arsthinol nanosuspensions: pharmacokinetics and anti-leukaemic activity on NB4 promyelocytic leukaemia cells., J. Pharm.

Pharmacol., 61 (2009) 1295-1301.

[14] S. Gibaud, S.B. Zirar, P. Mutzenhardt, I. Fries, A. Astier, Melarsoprolcyclodextrins inclusion complexes., Int. J. Pharm., 306 (2005) 107-121.

[15] J. Rodgers, A. Jones, S. Gibaud, B. Bradley, C. McCabe, M.P. Barrett, G. Gettinby, P.G.E. Kennedy, Melarsoprol cyclodextrin inclusion complexes as promising oral candidates for the treatment of human african trypanosomiasis, Plos Neglect. Trop. Dis., 5 (2011) e1308.

[16] I. Ajana, A. Astier, S. Gibaud, Speciation of arsenic in urine following intravenous administration of arsthinol in mice, Eur. J. Drug Metabol.

Pharmacokinet., 35 (2010) 59-65.

[17] E. Friedheim, Substituted [1,3,5-triazinyl-(6)]-aminophenyl-arsonic acids and process for manufacture of same, United States Patent 2,295,574, 1942.

[18] E. Friedheim, Heterocyclic metal and sulfur organic compounds, United States Patent, 1953.

[19] T. Higuchi, C. KA, Phase-solubility techniques, Adv. Anal. Chem. Instrum., 4 (1965) 117-212.

[20] C. Hiskey, F. Cantwell, Ultraviolet spectrum correlations with the conjugate acidbase species of acetarsone and arsthinol, J. Pharm. Sci., 57 (1968) 2105-2111.

[21] American Chemical Society Committee on Analytical Reagents, Reagent Chemicals: Specifications and Procedures, Oxford University Press, Washington, USA, 2006.

[22] C. Kahle, U. Holzgrabe, Determination of binding constants of cyclodextrin inclusion complexes with amino acids and dipeptides by potentiometric titration, Chirality, 16 (2004) 509-515.

[23] S. Elliot, B. Loper, Improved absorption tube for arsenic determinations, Anal. Chem., 46 (1974) 2256-2257.

[24] S. Soignet, W. Tong, S. Hirschfeld, R. Warrell, Clinical study of an organic arsenical, melarsoprol, in patients with advanced leukemia, Cancer Chemother. Pharmacol., 44 (1999) 417-421.

[25] T. Kanzawa, Y. Kondo, H. Ito, S. Kondo, I. Germano, Induction of autophagic cell death in malignant glioma cells by arsenic trioxide, Cancer Res., 63 (2003) 21032108.

[26] T. Kanzawa, L. Zhang, L. Xiao, I. Germano, Y. Kondo, S. Kondo, Arsenic trioxide induces autophagic cell death in malignant glioma cells by upregulation of mitochondrial cell death protein BNIP3, Oncogene, 24 (2005) 980-991. 
[27] I. Brandariz, E. Iglesias, Potentiometric characterisation of cyclodextrin inclusion complexes of local anaesthetics, Supramol. Chem., 23 (2011) 607-614.

[28] F.O. Yousef, M.B. Zughul, A.A. Badwan, The modes of complexation of benzimidazole with aqueous $\beta$-cyclodextrin explored by phase solubility, potentiometric titration, $1 \mathrm{H}-\mathrm{NMR}$ and molecular modeling studies, J. Incl. Phenom. Macrocycl. Chem., 57 (2007) 519-523.

[29] N. Funasaki, M. Nagaoka, S. Hirota, Competitive potentiometric determination of binding constants between alpha-cyclodextrin and 1-alkanols, Anal. Chim. Acta, 531 (2005) 147-151.

[30] E. Junquera, E. Aicart, A fluorimetric, potentiometric and conductimetric study of the aqueous solutions of naproxen and its association with hydroxypropyl-betacyclodextrin, Int. J. Pharm., 176 (1999) 169-178.

[31] J.P. Diard, E. Saint-Aman, D. Serve, Potentiometric association constant measurements of $\alpha, \beta$ or $\gamma$-cyclodextrin complexes involving iodide, tri-iodide or iodine species, J Electroanal. Chem. Interfacial Electrochem., 189 (1985) 113-120.

[32] K.A. Connors, J.M. Lipari, Effect of cycloamyloses on apparent dissociation constants of carboxylic acids and phenols: equilibrium analytical selectivity induced by complex formation., J Pharm. Sci., 65 (1976) 379-383.

[33] H. Brun, M. Paul, N. Razzouq, M. Binhas, S. Gibaud, A. Astier, Cyclodextrin inclusion complexes of the central analgesic drug nefopam., Drug Dev. Ind. Pharm., 32 (2006) 1123-1134.

[34] S. Ben Zirar, S. Gibaud, A. Camut, A. Astier, Pharmacokinetics and tissue distribution of the antileukaemic organoarsenicals arsthinol and melarsoprol in mice, J. Organomet. Chem., 692 (2007) 1348-1352.

Fig. 1: The chemical structure of STB.

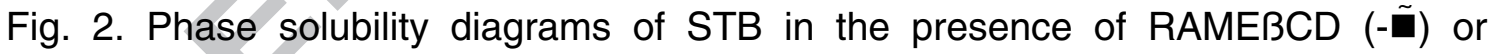
HPBCD (-O-) in distilled water at $25^{\circ} \mathrm{C}$. Mean \pm S.D.

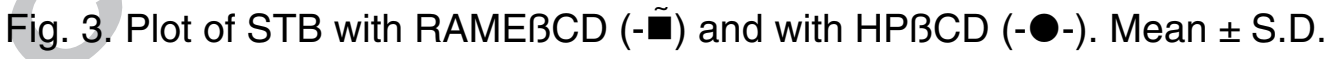

Fig 4a: ROESY spectrum of the complex (STB*HPBCD) obtained with a mixing time of $500 \mathrm{~ms}$. The cross peaks, surrounded by red circles, cannot clearly be attributed to intermolecular dipolar interactions [i.e., interaction of HPBCD protons with those of the aromatic moiety of STB]. 
Fig 4b: 2D HSQC-NOESY spectrum of the complex. Red dots indicate the HSQC peaks of the HPBCD, correlated with HSQC peaks of STB (e, e', f, red circles) via NOESY interaction (green circles).

Fig. 5. Molecular model of STB*HPBCD derived from the 2D HSQC-NOESY spectrum.

Fig. 6. Cytotoxicity parameters of STB, STB*HPBCD, $\mathrm{As}_{2} \mathrm{O}_{3}$ and melarsoprol on U87 cells. a) $I_{50}$. b) $I_{90}$. Mean \pm S.D.

Fig.7: Tumor growth after STB*HPBCD administration (- $\tilde{\mathbf{\Delta}}), \mathrm{As}_{2} \mathrm{O}_{3}$ administration (๘) and in control mice (-๑-). Starting value: $100 \%$ correspond to approximately 200 $\mathrm{mm}^{3}$ a) Intraperitoneal administration (65\% of the MTD). b) Oral administration $\left(\mathrm{As}_{2} \mathrm{O}_{3}-65 \%\right.$ of the MTD; STB*HPBCD - $10 \times$ MTD i.p. $) . n=9$ mice - Mean \pm SD. * $\mathrm{p}<0.05$ vs control, Mann-Whitney.

Fig. 8: Percent of mice bearing tumors $<2000 \mathrm{~mm} 3$ in the three treatment regiments. a) After intraperitoneal administration (65\% of the MTD). b) After oral administration $\left(\mathrm{As}_{2} \mathrm{O}_{3}-65 \%\right.$ of the MTD; STB*HPBCD - $10 \times$ MTD i.p. $) . \mathrm{n}=9$ mice.

Fig. 9: Survival days of each group (Control, $\mathrm{As}_{2} \mathrm{O}_{3}$ and $\mathrm{STB}^{*} \mathrm{HPBCD}$ ) after i.p. and oral treatment. Mean \pm S.D., $n=9 ;{ }^{*}: p<0.05$, Mann-Whitney

Table 1: ${ }^{1} \mathrm{H}$ NMR chemical shifts ( $($ ) of STB and hydroxypropyl- $\beta$-cyclodextrin (HPBCD)

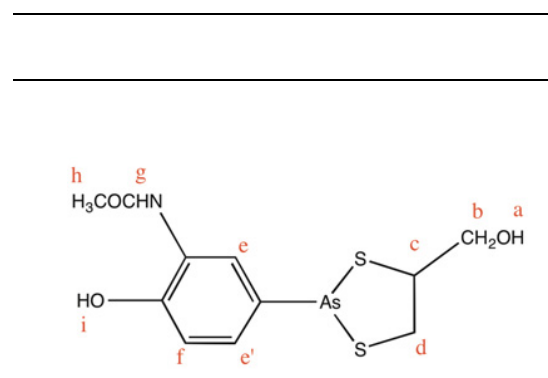

$$
\text { Proton Type }
$$$$
\delta(\mathrm{ppm})
$$

STB

$\begin{array}{cc}\mathrm{Ha} & 5.16 \\ \mathrm{Hb} & 3.31 \\ \mathrm{Hc} & 4.08 \\ \mathrm{Hd} & 2.92,3.84 \\ \mathrm{He}, \mathrm{Hf} & 6.92-8.07 \\ \mathrm{Hg} & 10.14 \\ \mathrm{Hh} & 2.15 \\ \mathrm{Hi} & 9.36\end{array}$


HPBCD

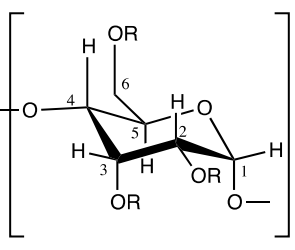

$\mathrm{H} 1$

5.05

$\mathrm{H} 2$

$\mathrm{H} 3$

$\mathrm{H} 4$

$\mathrm{H} 5$

$\mathrm{H} 6$

$3.5-3.9$

$\mathrm{R}=\mathrm{H}$ or 2-hydroxypropyl

Table 2: Maximum tolerated doses (MTD) of STB*RAMEBCD complex and $\mathrm{As}_{2} \mathrm{O}_{3}-$ daily doses proposed for the treatment of each group of mice.

\begin{tabular}{lcc}
\cline { 2 - 3 } & \multicolumn{1}{c}{ MTD* $^{*}$} & Treatment - daily dose \\
\hline STB/RAMEBCD i.p. & $0.18 \mathrm{mmol} / \mathrm{kg}$ & $\begin{array}{c}0.12 \mathrm{mmol} / \mathrm{kg} \\
(65 \% \mathrm{MTD} \text { i.p. })\end{array}$ \\
\hline $\mathrm{As}_{2} \mathrm{O}_{3}$ i.p. & $0.08 \mathrm{mmol} / \mathrm{kg}$ & $0.052 \mathrm{mmol} / \mathrm{kg}$ \\
& & $(65 \% \mathrm{MTD}$ i.p. $)$ \\
\hline STB/RAMEBCD oral & $>3 \mathrm{mmol} / \mathrm{kg}$ & $1.2 \mathrm{mmol} / \mathrm{kg}$ \\
& & $(10 \mathrm{fold} \mathrm{i.p.} \mathrm{dose})$ \\
\hline $\mathrm{As}_{2} \mathrm{O}_{3}$ oral & $0.4 \mathrm{mmol} / \mathrm{kg}$ & $0.26 \mathrm{mmol} / \mathrm{kg}$ \\
& & $(65 \% \mathrm{MTD}$ oral $)$ \\
\hline
\end{tabular}

* The maximum tolerated dose (MTD) was determined after 3 weeks of treatment in 5 mice. Criteria: no weight loss of $\geq 15 \%$ and no death. 
Table 3: Amount of arsenic in organs of mice treated with STB*HPBCD during 28 days..

\section{Amount of arsenic ( $\mathrm{nmol} / \mathrm{g}$ of tissue)}

\begin{tabular}{ccccccc}
\hline & Kidney & Intestine & Tumor & Liver & Brain & Spleen \\
\hline \multirow{2}{*}{ i.p } & \multirow{2}{*}{ ND } & \multirow{2}{*}{ ND } & 21,3 & 44 & 693 & \\
\cline { 3 - 6 } & & & $(\mathrm{n}=2)$ & $(\mathrm{n}=1)$ & $(\mathrm{n}=2)$ & ND \\
\hline \multirow{2}{*}{ Per os } & $84 \pm 61$ & 202 & 14 & 12 & 217 & 31 \\
\cline { 2 - 6 } & $(\mathrm{n}=3)$ & $(\mathrm{n}=2)$ & $(\mathrm{n}=2)$ & $(\mathrm{n}=2)$ & $(\mathrm{n}=2)$ & $(\mathrm{n}=1)$ \\
\hline
\end{tabular}

Mice alive at the end of the study (STB/HPBCD, day 28) are indicated in parentheses.

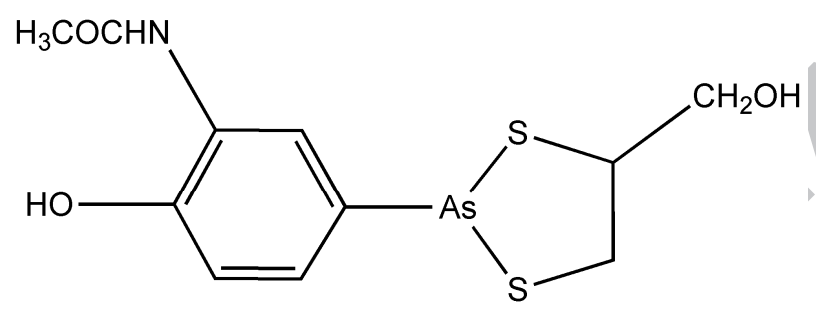

Arsthinol

Chemical Formula: $\mathrm{C}_{11} \mathrm{H}_{14} \mathrm{AsNO}_{3} \mathrm{~S}_{2}$

Molecular Weight: 347,29 


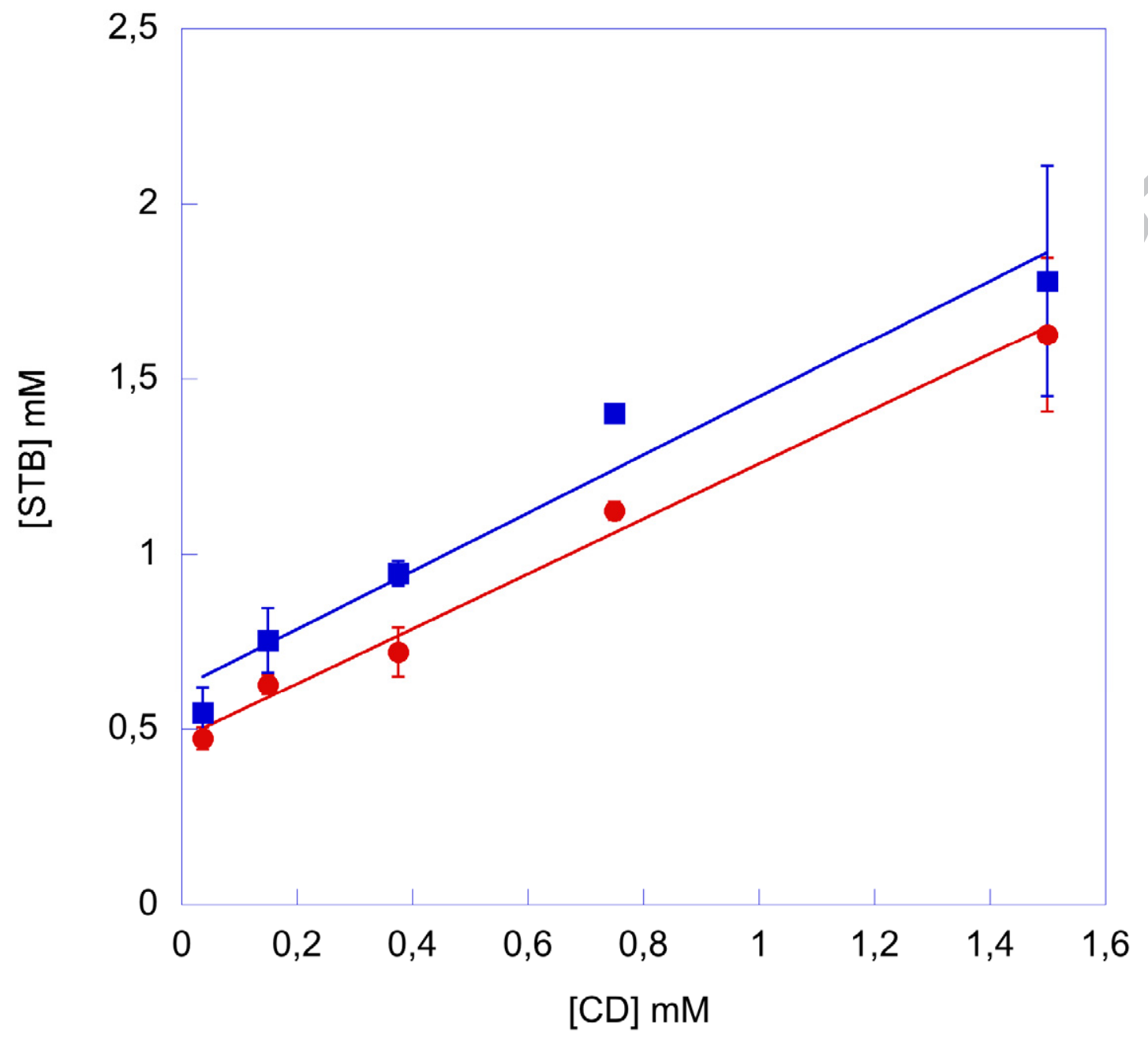




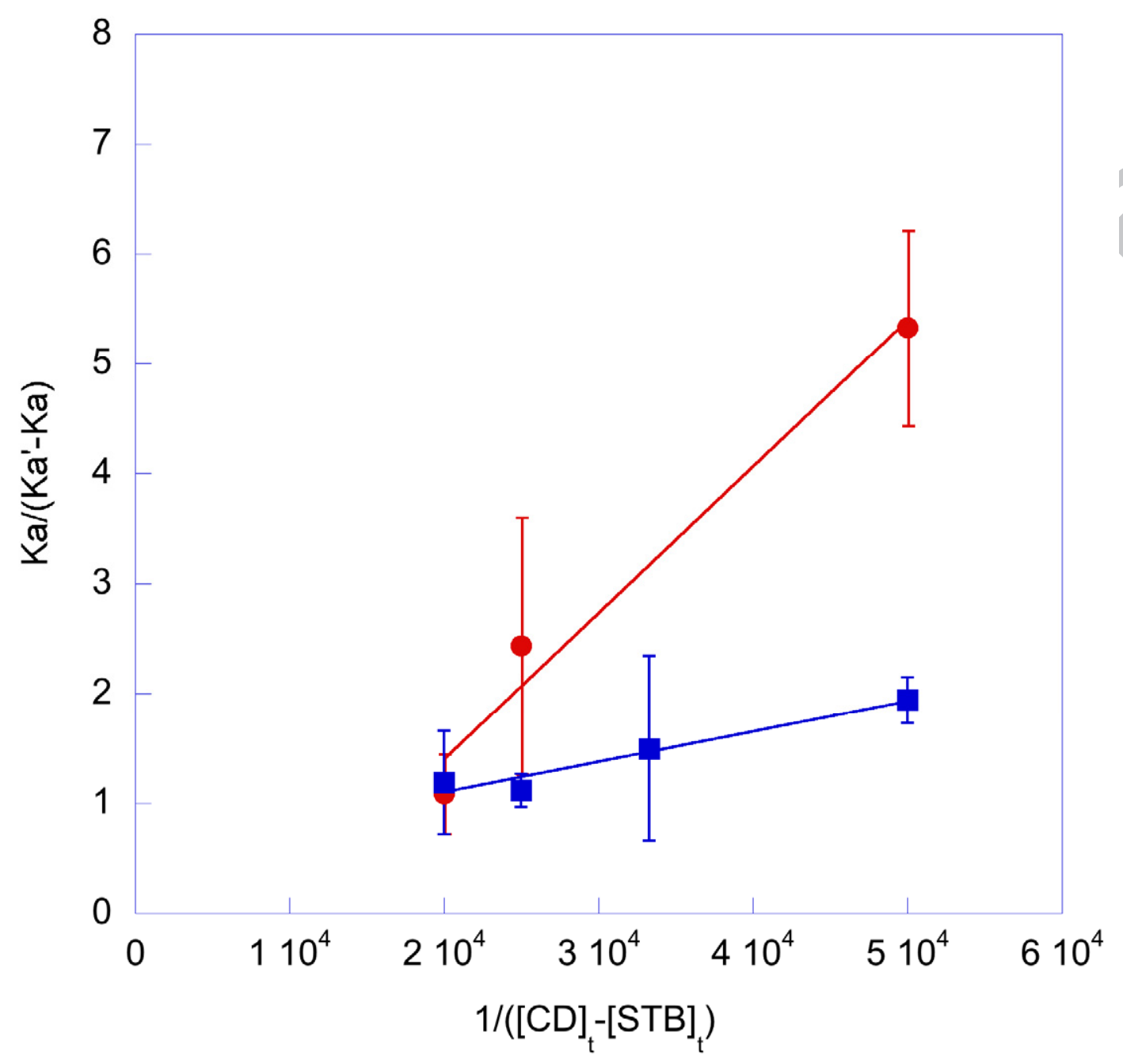




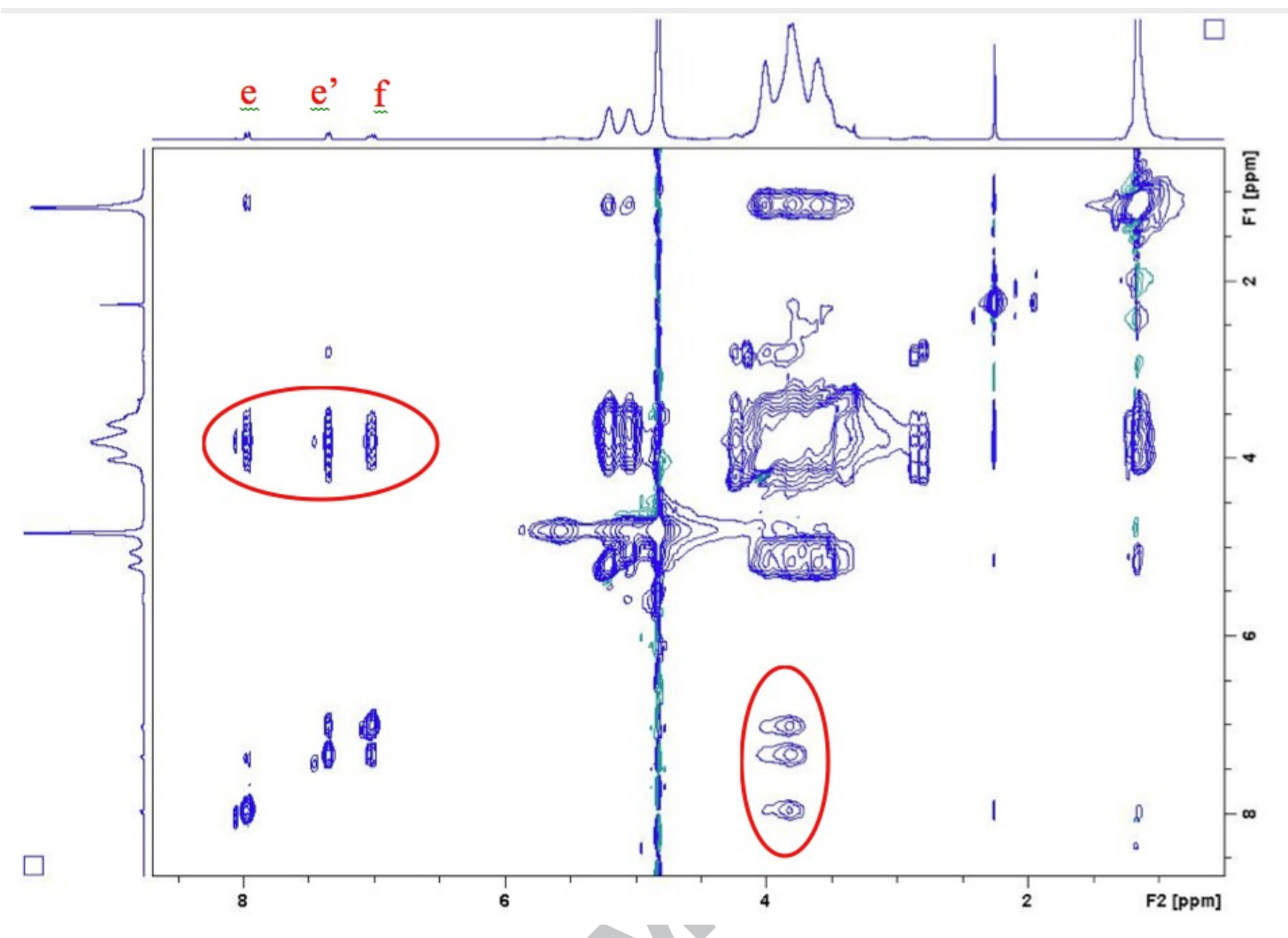




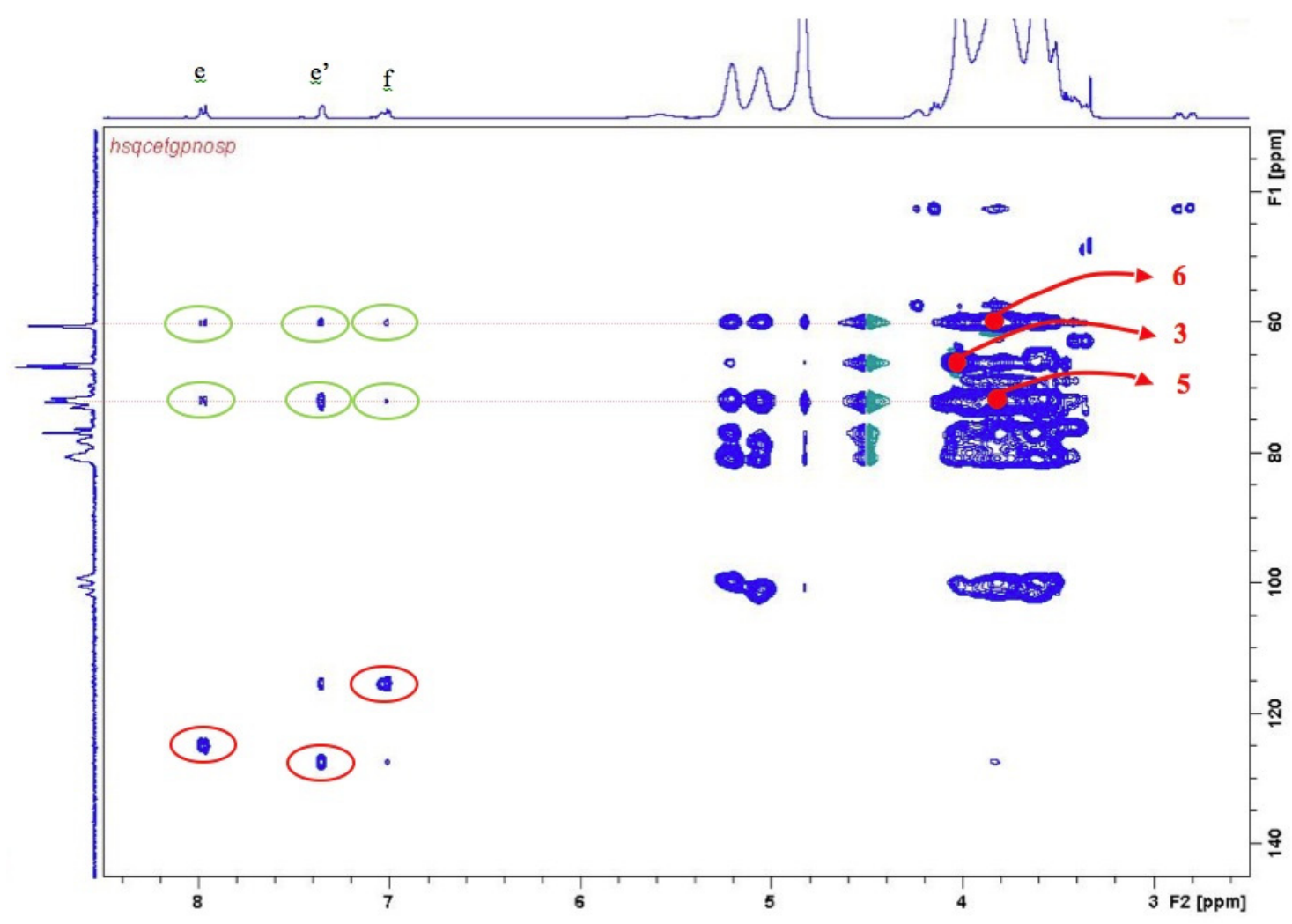




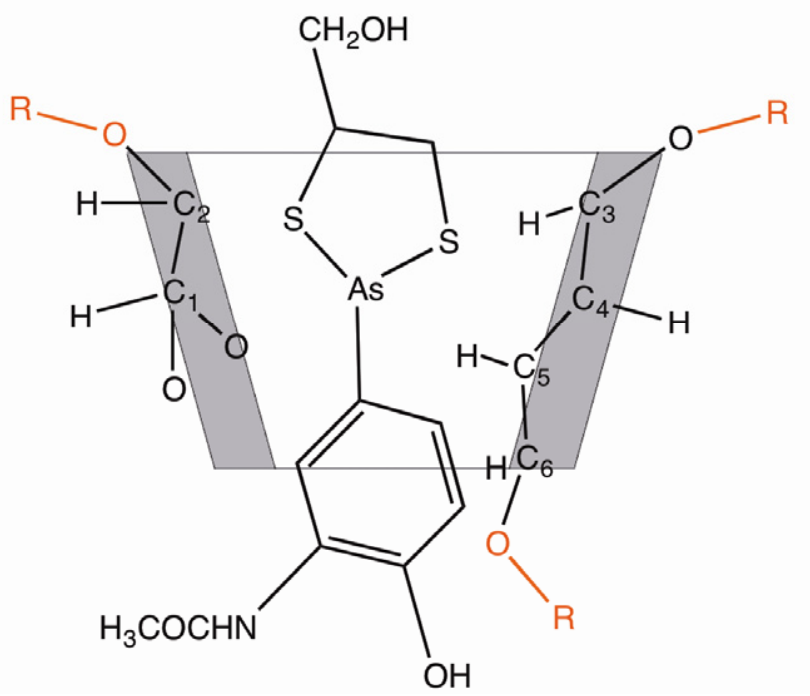




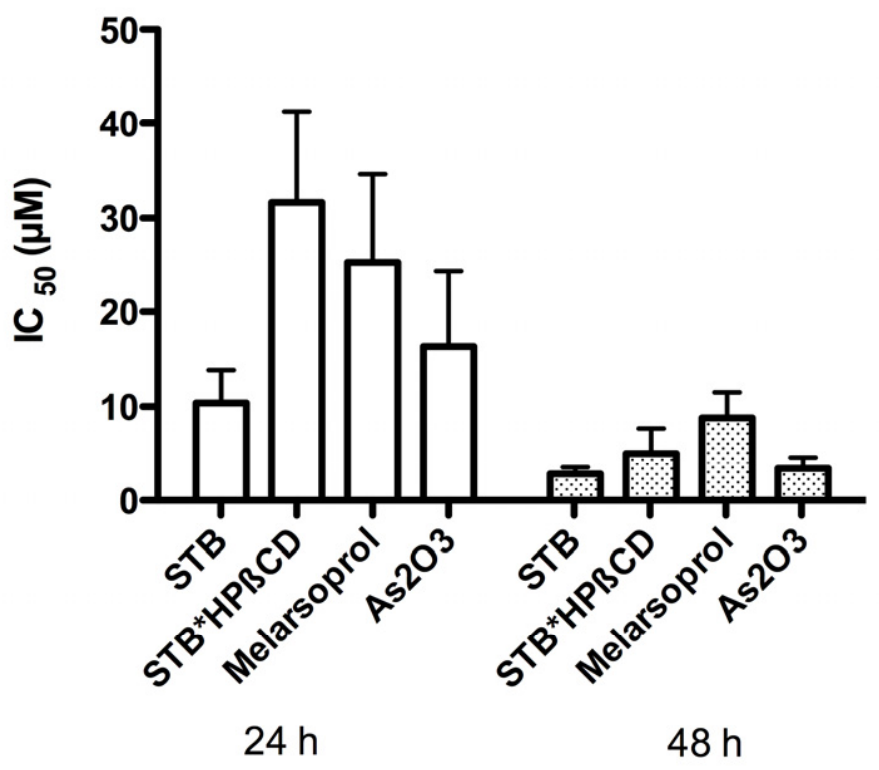




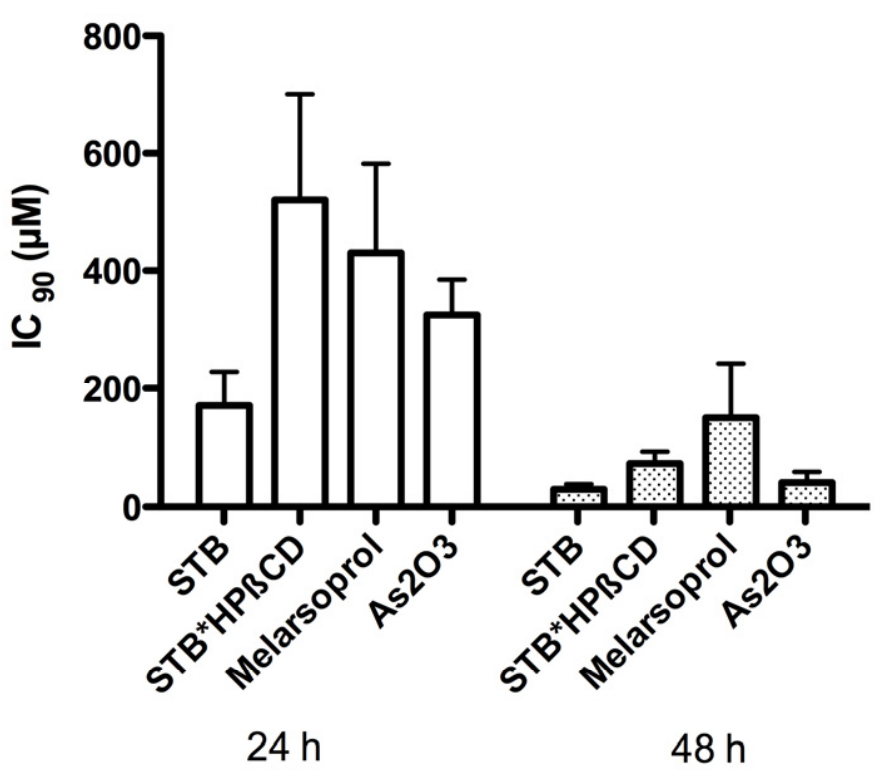




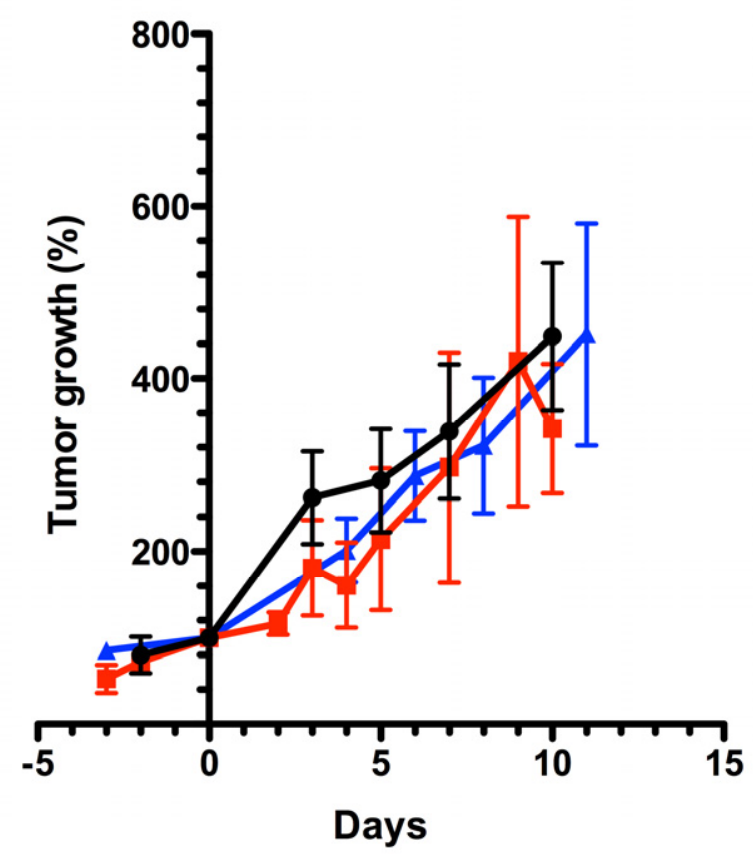




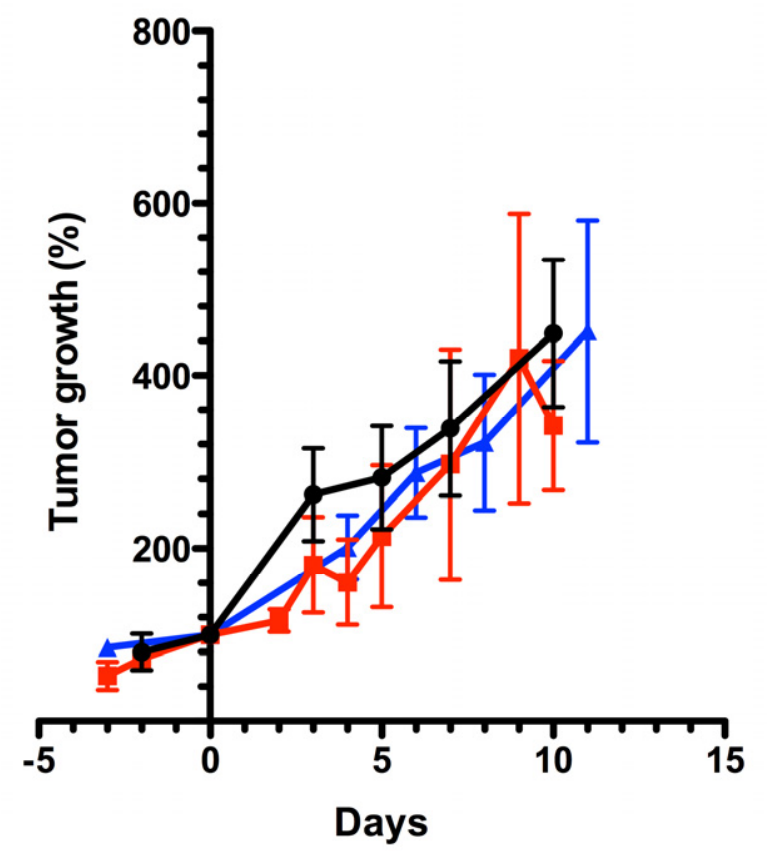




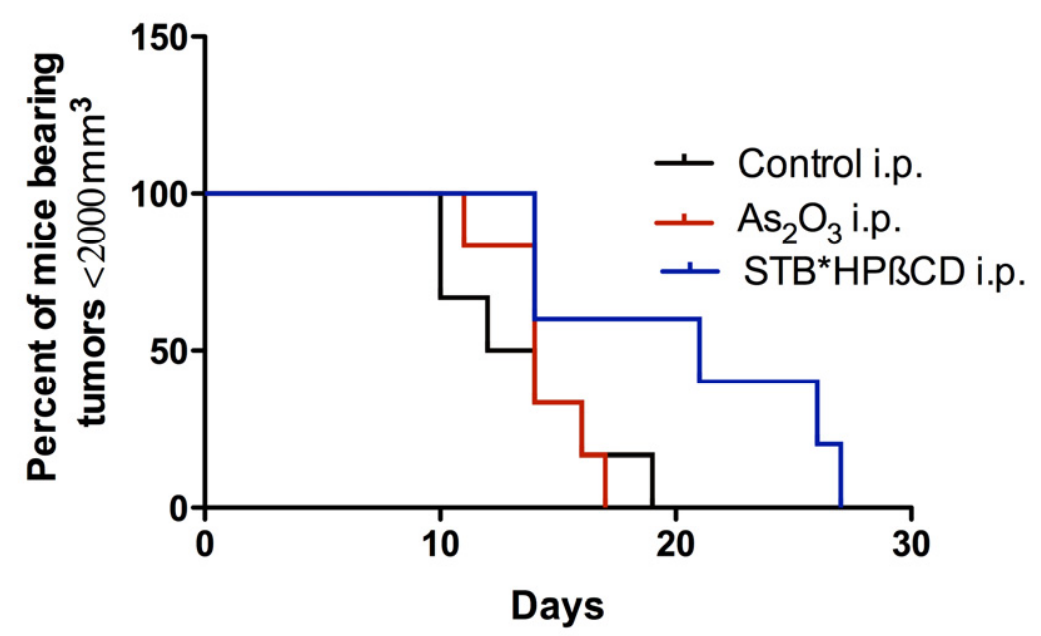




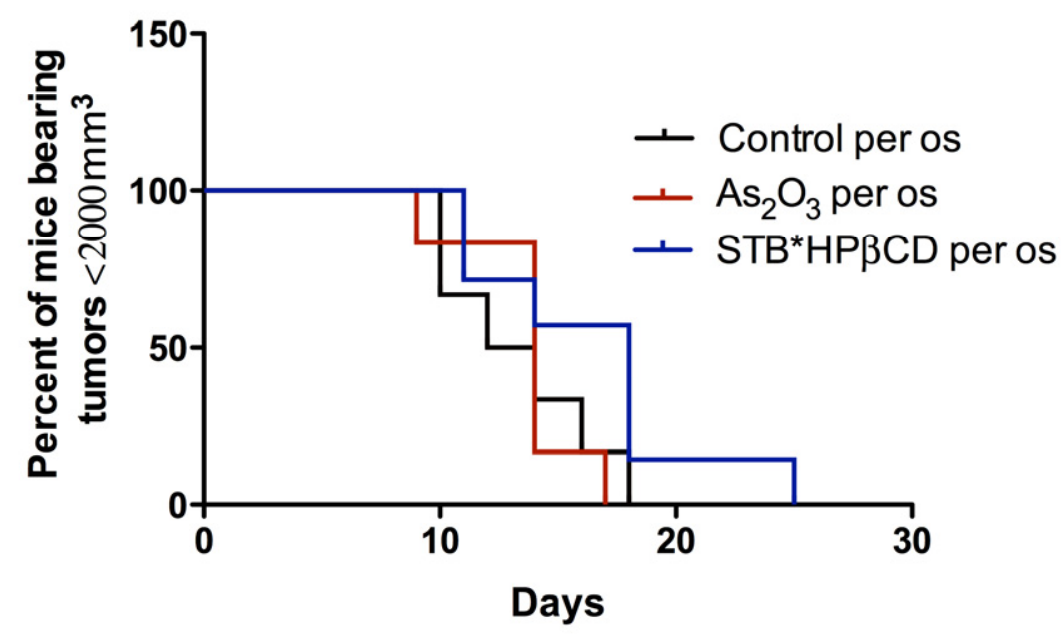




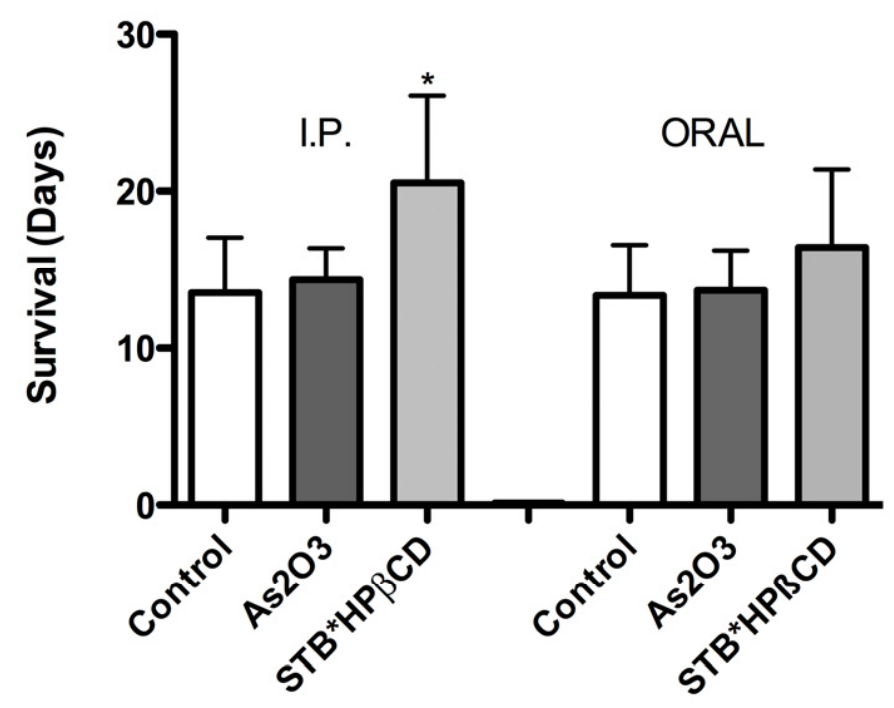




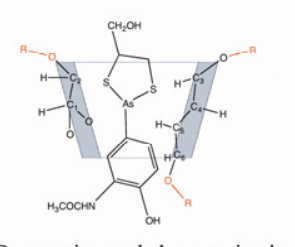

1) Preparation and characterization of an arsthinol/hydrocypropyl- $\beta$ cyclodextrin complex

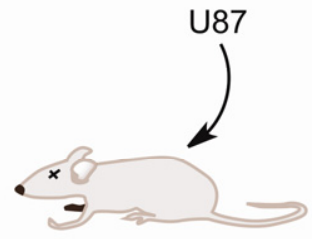

2) Implantation of tumors (U87 glioma cell line)

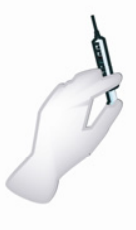

3) Administration of the arsthinol/hydroxypropylarsthinol/hydroxypropyl-
B-cyclodextrin complex or As2O3

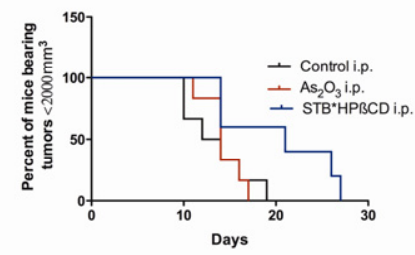

4) Survival study 